\title{
Öğretmenlerin Mesleki Profesyonelliği İle İş Doyumları
}

\section{Arasındaki İlişki}

\author{
Yahya ALTINKURT ${ }^{*}$
}

Kürşad YILMAZ ${ }^{* *}$

Öz

Bu çalışmanın amacı, öğretmenlerin mesleki profesyonelliği ile iş doyumları arasındaki ilişkiyi belirlemektir. Tarama modelindeki araştırmanın örneklemi Kütahya il merkezindeki okullarda görev yapan 363 öğretmenden oluşmaktadır. Veriler, Öğretmenlerin Mesleki Profesyonelliği Ölçeği ve İş Doyumu Ölçeği ile toplanmıştır. Öğretmenlerin Mesleki Profesyonelliği Ölçeği, Kişisel Gelişim, Kuruma Katkı, Mesleki Duyarll1ık ve Duygusal Emek olmak üzere dört faktörden oluşmaktadır. Verilerin analizinde betimsel istatistikler, t-testi, ANOVA ve Pearson korelasyon katsayısı kullanılmıştır. Elde edilen sonuçlara göre öğretmenler, orta düzeyde bir profesyonellik algısına ve iş doyumuna sahiptir. Katılımcıların, kuruma katkı boyutundaki görüşleri cinsiyete ve görev yapılan okul türüne; duygusal emek boyutlarındaki görüşleri görev yapılan okul türüne; kişisel gelişim boyutundaki görüşleri görev yapılan okul türüne; iş doyumu ile ilgili görüşleri görev yapılan okul türüne ve okuldaki öğretmen sayısına göre değişmektedir. Katılımcıların hiçbir boyuttaki görüşü kıdeme göre değişmemektedir. Katılımcıların, kuruma katkı, kişisel gelişim ve mesleki duyarlılık ile ilgili görüşleri ile iş doyumu arasında düşük düzeyde, aynı yönde ve anlamlı; duygusal emek ve mesleki profesyonellik toplam puan ile ilgili görüşleri arasında ise orta düzeyde, aynı yönde ve anlamlı ilişkiler vardır.

Anahtar Kelimeler: Mesleki profesyonellik, iş doyumu, kamu okulları.

\section{Relationship between Occupational Professionalism of Teachers and Their Job Satisfaction}

\begin{abstract}
The purpose of this research is to determine the relationship between occupational professionalism of teachers and their job satisfaction. Designed in survey method, the sample of this research is comprised of 363 teachers working in schools in Kütahya city center. Data was collected using the Occupational Professionalism of Teachers Scale and Job Satisfaction Scale. The Occupational Professionalism of Teachers Scale is comprised of four factors, namely Personal Development, Contribution to Organization, Professional Awareness and Emotional Labor. Data analysis has included descriptive statistics, t-test, ANOVA and Pearson correlation coefficient. Results have shown that teachers have a medium level of perception for professionalism and job satisfaction. The participants' opinions under the "contribution to organization" dimension vary in relation to gender and school type, their opinions under the "emotional labor" dimension vary in relation to school type, their opinions under the "personal development" dimension vary in relation to school type, and their opinions about job satisfaction vary in relation to school type and the number of students working in their organization. The participants' opinions do not vary based on seniority under any dimension. There is a low, even and significant relationship between the participants' views
\end{abstract}

* Doç. Dr., Muğla Sıtkı Koçman Üniversitesi Eğitim Fakültesi - yaltinkurt@gmail.com

** Doç. Dr., Dumlupınar Üniversitesi Eğitim Fakültesi - kursadyilmaz@gmail.com 
about contribution to organization, personal development and professional awareness and their job satisfaction; and there are moderate, even and significant relationships between emotional labor and occupational professionalism total score and their relevant views.

Keywords: Occupational professionalism, job satisfaction, public schools.

\section{GİRiş}

Çalışanların mesleki profesyonelliklerine yapılan vurgunun gün geçtikçe arttı̆̆ görülmektedir. $\mathrm{Bu}$ vurgunun artmasında gün geçtikçe karmaşık hale gelen örgütsel yaşamda, çalışanların profesyonelliklerine daha fazla ihtiyaç duyulmasıdır. Örgütsel yaşamın karmaşıklığı çalışanların davranışlarında amatörce değil, profesyonelce davranmaların gerekli kılmaktadır. Amatörlük, “Bir işi para kazanmak için değil, yalnız zevki için yapmak, hevesli, meraklı (kimse), profesyonel karşıtı; bir işi meslek veya alan uzmanı olmadan yapmak (Türk Dil Kurumu, 2005)" olarak tanımlamaktadır. Freidson'a (2001) göre profesyonel, belli bir gelir elde etmek amaciyla işini yapan, bunu yaparken belli bir takım bilgi ve beceriye ihtiyaç duyan ve kişinin işini yaparken yeterliğini ifade eden bir kavramdır. Bir işi en düzgün ve özenli, bununla beraber en az hata ile yerine getirmek profesyonelliğin göstergesidir. Profesyonelliğin göstergelerinden bir diğeri de çalışılan işi en küçük detaylarına kadar anlama, uygulama ve bütün püf noktalarını bilerek beklentilerin üzerinde bir iş ortaya koymaktır (Adıgüzel, Tanrıverdi ve Sönmez-Özkan, 2011).

Bu kapsamda profesyonelliği, yüksek standartları gerçekleştirmek ve hizmetin niteliğini iyileştirmek için davranışları ve tutumlarını kapsayan çok boyutlu bir yapı olarak yorumlamak olasıdır. Profesyonellik, niteliklerin ve kazanılan kapasitelerin ne olduğu sorusuna ve bir işin başarılı uygulamaları için gerekli olan yeterliklere odaklanmaktadır (Demirkasımoğlu, 2010). Evans (1999) profesyonelliği, mesleki uygulamaları etkileyen ideolojik, davranışsal, entelektüel ve epistemolojik temelli bireysel bir duruş olarak tanımlamaktadır. Bu bağlamda profes- yonellik, profesyonel vasıflar, tutumlar, etkileşimler ve davranışlarla ilgili içselleştirilmiş inançlardır (Swisher ve Page, 2005)

Mesleki profesyonellik ise, bireysel profesyonelliğin örgütsel profesyonelliğe yerini bırakmasıdır. Ayrıca mesleki profesyonellik, mesleki standartların belirlenmesi ve hizmet kalitesinin yükseltilmesinde temel etkenler arasinda yer almaktadır (Adıgüzel ve diğerleri, 2011). Mesleki profesyonellik örgüt açısından önemli olduğu kadar, çalışan açısından da son derece önemlidir. Mesleki profesyonelliği çalışan açsindan önemli hale getiren en önemli konu performansın tesadüflere bırakılamaması, işin çalışanı motive etmesi gereği ve çalışanın yaptığ1 işten doyum sağlamasıdır. Bu bağlamda çalışanların mesleki profesyonellikleri ile iş doyumları arasındaki ilişkinin belirlenmesi örgütsel yaşam açısından önemli olabilir.

$\mathrm{Bu}$ çalı̧̧mada öğretmenlerin mesleki profesyonelliği şu alt boyutlarda incelenmiştir: 1) Kişisel gelişim 2) Kuruma katkı 3) Mesleki duyarlılık, 4) Duygusal emek.

Kişisel gelişim. Çalışanların zorunlu olmamasına rağmen, mesleklerini daha iyi yapabilmek için kendilerini geliştirme çabası içerisinde olmasıdır (Murphy ve Calval, 2008). Örneğin, doktora yapma fırsatı olmamasına rağmen, kendini geliştirmek amacı ile tezsiz yüksek lisans programlarına devam eden ve üstelik buna bir de belli bir miktar ücret veren eğitimcilerin bu davranışı tam olarak bir mesleki profesyonellik davranışıdır. Bu boyut, McMahon ve Hoy'un (2009) çalışmasındaki akademik sorumluluk boyutu ile benzerlik göstermektedir. Öğretmenlerin alanları ile ilgili bilimsel yayınları, 
kitapları ya da etkinlikleri takip etmesi, alanlaryyla ile ilgili olmasa bile düzenli olarak kitap okuması bu mesleğe yönelik kişisel gelişim çabası olarak değerlendirilebilir.

Kuruma katkı. Öğretmenlerin sahip olduğu bilgi, birikim, deneyim ve çevresindeki ilişkilerini kurum yararına kullanmasıdır. Bu anlamda mesleki profesyonelliği yüksek düzeyde olan öğretmenler; okuldaki sosyal, kültürel ve meslekî çalışmalara, projelere gönüllü ve aktif bir biçimde katılma, kendi çevresindeki olanakları okul yararına işe koşma gibi davranışlarda bulunurlar.

Mesleki duyarllık. Mesleki duyarlılığı yüksek olan öğretmenler, gereksinimlerinin farkında olan, yeni fikirlere ve değişime açık, meslektaşlarıyla iletişim ve işbirliği içinde, mesleki etik ilkelere duyarlı, işini en iyi biçimde yapma gayretinde olan ve davranışlarıyla öğrencilere rol model olan profesyonellerdir.

Duygusal emek. Öğretmenlerin mesleki profesyonelliğin bir gereği olarak, örgütsel amaçlara ve çalışma ortamında uygun davranışlar sergileyebilmeleri için gerçek duygularını düzenlemesi ve duygularını yönetmesidir (Isenbarger ve Zembylas, 2006; Diefendorff, Croyle ve Grosserand, 2005; Basım ve Begenirbaş, 2012). Yani duygusal emek, çalışanların iş ortamında bir anlamda rol yapmasıdır. Bu anlamda mesleki profesyonellik düzeyleri yüksek olan öğretmenler; okul yönetimiyle, meslektaşlarıyla ya da özel yaşamında sorunları olsa bile bunu işine ve ilişkilerine yansıtmamaya çalışırlar.

İş doyumu, en basit anlatımı ile çalışanların işlerinden hoşlanma ve memnun olma derecesi (Locke, 1983; Muchinsky, 2006; Spector, 1997), çalışanın işinde mutlu olması ve tatmin edilmesi ile ilgili bir derece durumu (Hackman ve Oldham, 1975) olarak tanımlanabilmektedir. Bu bağlamda iş doyumunun, çalışanların işleri ile ilgili algıları toplamı olduğu ve bu algının ihtiyaçların giderilmesi ile yakından ilgili oldu- ğu söylenebilir. Balcı'ya (1985) göre iş doyumunda, işe ait özelliklerde bireyin değer ve beklentilerin ne düzeyde karşılandığı ve bu karşılanma durumunun çalışan tarafından ne düzeyde algılandığı önemlidir. İş doyumun üç önemli boyutu vardır: 1) İş doyumu, bir iş durumuna duygusal yanittır. Böyle olunca görülmez, sadece ifade edilebilir. 2) İş doyumu genellikle, kazançların ne ölçüde karşılandığg veya beklentilerin ne kadar aşıldığının belirlenmesidir. 3) İş doyumu, işin kendisi, ücret, terfi olanakları, yönetim tarzı, çalışma arkadaşları gibi birbiriyle ilişkili çeşitli tutumları temsil etmektedir (Luthans, 1992).

İş doyumu yüksek olan çalışanlar, daha sağlık1 , daha mutlu olmakta, mutluluğunu iş dışına taşımakta, yaşamın diğer alanlarında da mutlu olmaktadır. Bu bağlamda çalışanlarda iş doyumunun yüksek olmasının örgütsel yaşama birçok olumlu etkisi vardır. Örneğin, çalışanların işe devamsızlığı azalmakta, çalışan devir oranı düşmekte, çalışanların gönüllü davranışları artmakta, iletişim becerileri gelişebilmekte, verimlilik artabilmektedir. İş doyumunun düşük olması ise, yabancılaşma, işin anlamsızlaşması, saldırgan tepkiler, olumsuz bir iletişim tarzı, değişime direnç, huzursuzluklar, yoğun dedikodu, işi geciktirme, verimsizlik, kurallara uymama ve daha birçok olumsuz sonuç ortaya çıarabilmektedir.

Çalışanların iş doyumunu etkileyen unsurlar olarak birçok değişken sıralanmaktadır. Ancak genel olarak bu değişkenleri örgütsel unsurlar ve kişisel unsurlar olmak üzere iki başlık altında incelenmektedir. Örgütsel unsurlar arasında, örgüt ve yönetim, denetim, işin niteliği, görev yapılan birimin özellikleri, ücret, terfi olanaklarl, sosyal haklar, ödül ve ceza sistemi, takdir edilmek, diğer çalışanlar, iletişim biçimi, güvenlik, fiziksel çalışma koşulları gibi unsurlar sayılmaktadır. Bireysel unsurlar ise çalışanın kendisi ile ilgili bütün özellikleri kapsamakla 
birlikte genel olarak yaş, kişilik özellikleri, cinsiyet, zekâ, eğitim düzeyi, mesleki kıdem, medeni durum ve yetenek başlıkları altında incelenmektedir. Bu çalışmada örgütsel unsurlardan okul türü ve okuldaki öğretmen sayısı, bireysel unsurlardan da mesleki profesyonellik, cinsiyet ve kıdem bağımsız değişken olarak ele alınmıştır.

İş doyumu, bireyin işi ile ilgili algısı olduğundan en önemli belirleyiciler, iş ve örgüt ile ilgili özelliklerdir. Ancak iş ve örgüt ile ilgili özelliklerin algılanış biçiminin en önemli belirleyicisi ise bireysel özelliklerdir. Örneğin, genel olarak olumsuz düşünen bir birey, iş ile ilgili özellikleri de olumsuz algılama eğilimindedir. Mesleki profesyonellik de, iş doyumunu etkileyebilecek kavramlardan biridir. Daha önce yapılan araştirmalarda da (Boyt, Lusch ve Naylor, 2001; Pearson ve Moomaw, 2005; Y1lmaz, Korkut ve Köse, 2010) profesyonelliğin iş doyumu ile anlamlı bir ilişkisi olduğu sonucuna ulaşılmıştır. Türkiye'de öğretmenlerin mesleki profesyonelliği ile ilgili araştırmalar (Bayhan, 2011; Cerit, 2012) olsa da mesleki profesyonellik ile iş doyumu arasındaki ilişkiyi eğitim kurumlarında araştıran bir çalışmaya ulaşılamamıştır. Buna göre araştırmanın amacı öğretmenlerin mesleki profesyonelliği ile iş doyumları arasındaki ilişkinin belirlenmesidir. Bu genel amaca ulaşmak için şu sorulara yanıt aranmıştır:

1. Öğretmenlerin mesleki profesyonellik ve iş doyumu ile ilgili görüşleri nasıldır?

2. Öğretmenlerin mesleki profesyonellik ve iş doyumu ile ilgili görüşleri cinsiyet, okul türü, kıdem ve okuldaki öğretmen sayısına göre değişmekte midir?

3. Öğretmenlerin mesleki profesyonellik ve iş doyumu ile ilgili görüşleri arasında anlamlı bir ilişki var mıdır?

\section{YÖNTEM}

Araştırma tarama modelindedir. Katılımcıların görüşleri betimlenmiş, çeşitli değişkenlere göre karşılaştırılmış ve aradaki ilişki belirlenmeye çalışılmıştır.

\subsection{Evren-Örneklem}

Araştırmanın evreninde 2013-2014 eğitim öğretim yılında, Kütahya il merkezinde görev yapan 5600 öğretmen bulunmaktadır. Örneklem büyüklüğü \% 95 güven düzeyi için 360 olarak hesaplanmıştır. Örnekleme girecek öğretmenlerin belirlenmesinde ise oransız küme örnekleme tekniği kullanılmıştır. Geri dönüşünde eksiklikler ve özensiz doldurma olabileceği ihtimali göz önünde bulundurularak 400 öğretmenden veri toplanmıştır. Veri toplama araçlarından kullanılabilir durumda olan 363 tanesi ile analizler yapılmıştır. Katılımcıların 161'i kadın (\% 44.4), 202'si erkektir (\% 55.6). Öğretmenlerin 36's1 okulöncesi eğitim kurumunda (\% 9.9), 84'ü (\% 23.1) ilkokulda, 99'u (\% 27.3) ortaokulda, 97'si (\% 26.7) meslek lisesinde, 47 'si ise (\% 12.9) genel liselerde görev yapmaktadır. Katılımcıların 94'ünün kıdemi 1-5 yıl (\% 25.9), 102'sinin kıdemi 6-10 yıl (\% 28.1), 75'inin k1demi 11-15 yıl (\% 20.7), 41'inin kıdemi $16-20$ yıl (\% 11.3), 49'unun ise 21 yıl ve üstündedir (\% 13.5). Öğretmenlerin 188'inin çalıştığ1 okuldaki toplam öğretmen sayısı 1-25 (\% 51.8), 98 'inin $26-50$ (\% 27.0), 72'sinin ise 51 ve üstündedir (\% 19.8).

\subsection{Veri Toplama Araçları}

Veriler, Öğretmenlerin Mesleki Profesyonelliği Ölçeği ve İş Doyumu Ölçeği ile toplanmıştır. Öğretmenlerin Mesleki Profesyonelliği Ölçeği, Yılmaz ve Altınkurt (2014) tarafından geliştirilmiş ve öğretmenlerin mesleki profesyonellikleri ile ilgili görüşlerini belirlemek amacı ile hazırlanmıştır. Ölçek Likert tipi 24 maddeden ve Kişisel Gelişim, Kuruma Katkı, Mesleki Duyarlılık ve Duygusal Emek alt boyutlarından 
oluşmaktadır. Söz konusu dört faktörlü yapı, toplam varyansın \% 52.22'sini açılamaktadır. Doğrulayıcı faktör analizi (DFA) ile elde edilen bulgular değerlendirildiğinde $\chi 2 / s d$ oran 12.66 bulunmuştur. DFA ile hesaplanan diğer uyum iyiliği indeksleri şöyledir: GFI $=0.82$, AGFI= $0.78, \mathrm{RMSEA}=0.08, \mathrm{RMR}=0.05, \mathrm{SRMR}=0.08$, $\mathrm{CFI}=0.80, \mathrm{NFI}=0.72, \mathrm{NNFI}=0.77, \mathrm{PGFI}=0.67$. Ölçeğin güvenirliğini test etmek için son olarak Cronbach Alfa iç tutarlılık katsayılarına $(\alpha)$ bakılmıştır. Bu katsayı "kişisel gelişim” faktörü için .79, "mesleki duyarlılı" faktörü için .74 "kuruma katkı" faktörü için .86, ve "duygusal emek" faktörü için .80 ve ölçeğin tümü için .90 olarak hesaplanmıştır. Ölçekte yer alan maddeler, 1-kesinlikle katılmiyorum ile 5-kesinlikle katılıyorum" aralığında puanlanmaktadır. Ölçekten alınan puanın yükselmesi yanıtlayan kişinin mesleki profesyonelliği ile ilgili olumlu görüşüne, düşmesi ise olumsuz görüşüne işaret etmektedir.

İş Doyum Ölçeği, Hackman ve Oldham (1975) tarafından geliştirilmiş, Silah (2002) tarafından Türkçeye uyarlanmıştır. Bu ölçek Taşdan (2008) tarafından öğretmenler üzerinde uygulanmış, geçerlik ve güvenirlik analizleri yapılmıştır. Ölçek, 14 maddeden oluşmakta ve her bir ifade Likert tipi beşli dereceleme üzerinden değerlendirilmektedir. Ölçek, "1-Beni hiç tatmin etmez" ve "5-Beni çok tatmin eder" aralığında puanlanmaktadır. Ölçekten elde edilen yüksek puan öğretmenlerin iş doyumlarının yüksek olduğunu göstermektedir. Taşdan'ın (2008) öğretmenler üzerinde yapmış olduğu uygulama sonuçlarına göre ölçekte yer alan maddelerin faktör yük değerleri 0.69 ile 0.86 , madde toplam korelasyonları ise 0.66 ile 0.84 arasında değişmektedir. Ölçeğin açıladığı toplam varyans \% 64'tür. Ölçeğin Cronbach's Alfa iç tutarlılık katsayısı ise .95 'tir. Ölçeğin bu araştırmadaki Cronbach's Alfa Güvenirlik Katsayısı ise $.88^{\prime} \mathrm{dir}$

\subsection{Verilerin Analizi}

Verilerin analizinde öğretmenlerin mesleki profesyonellik ve iş doyumu ile ilgili görüşlerinin belirlenmesinde betimsel istatistikler; kat1lımcların görüşlerinin cinsiyete göre karşılaştırılması için t-testi, okul türü, kıdem ve okuldaki öğretmen sayısına göre karşılaştırılması için ANOVA analizleri kullanılmıştır. Öğretmenlerin mesleki profesyonelliği ile iş doyumları arasındaki ilişki ise Pearson Korelasyon Katsayısı ile belirlenmeye çalışılmıştır. Korelasyon katsayısının mutlak değer olarak, 0.70-1.00 arasında olması yüksek; 0.69-0.30 arasında olması orta; 0.29-0.00 arasında olması ise düşük düzeyde ilişki olarak tanımlanmıştır (Büyüköztürk, 2009).

\section{BULGULAR}

Araştırmaya katılan öğretmenler ( $\mathrm{n}=363)$ mesleki profesyonellik boyutları arasında en yüksek katılımı sırası ile Mesleki Duyarlılık ( $\mathrm{AO}=4.41, \mathrm{~S}=.56-$ Kesinlikle katıliyorum), Duygusal Emek ( $\mathrm{AO}=4.24, \mathrm{~S}=.53$-Kesinlikle katıliyorum), Kuruma Katk1 ( $\mathrm{AO}=3.62, \mathrm{~S}=.62-$ Katıliyorum) ve Kişisel Gelişim ( $\mathrm{AO}=3.51, \mathrm{~S}=.62-$ Katılıyorum) boyutlarına göstermiştir. Katılımcıların Mesleki Profesyonellik Toplam puandaki görüşleri de $(\mathrm{AO}=3.92, \mathrm{~S}=.45)$ Katıliyorum yanıtına daha yakındır.

Katılımcilar, mesleki duyarlılık boyutunda yer alan beş maddenin tamamına "Kesinlikle Katılıyorum" yanıtını vermiştir. Katılımcıların en yüksek katılım gösterdiği madde “Meslektaşlarımla bilgi alış verişinde bulunmak benim için önemlidir ( $\mathrm{AO}=4.55, \mathrm{~S}=.75)$ " maddesi iken en düşük katılım gösterilen madde “Öğretmenliğimle ilgili konularda geri bildirim almaktan mutlu olurum $(\mathrm{AO}=4.22, \mathrm{~S}=.86)$ " maddesidir.

Araştırmaya katılan öğretmenler duygusal emek boyutunda yer alan altı maddenin üçüne “Kesinlikle Katılıyorum”, üçüne ise "Katılıyorum" yanıtını vermiştir. Katılımcıların en yük- 
sek katılım gösterdiği madde “Öğretmenlik mesleği etik ilkelerine uygun davranırım $(\mathrm{AO}=4.57, \mathrm{~S}=.59)$ " maddesi, en düşük katılım gösterdiği madde ise "Öğrenci velilerine, çocuklarının gelişimi konusunda düzenli geri bildirimde bulunurum $(\mathrm{AO}=3.94, \mathrm{~S}=.85)^{\prime \prime}$ maddesidir.

Kuruma katkı boyutunda yer alan sekiz maddenin yedisine "Katıliyorum", birine ise "Orta Derecede Katılıyorum" yanıtı verilmiştir. Bu boyutta en yüksek katılım "Bilgi ve iletişim teknolojilerini dersi geliştirmek için kullanırım $(\mathrm{AO}=4.05, \mathrm{~S}=.89)^{\prime}$, en düşük katılım ise "Okuldaki sorunlar ile ilgili bilimsel araştırmalar yaparım ( $\mathrm{AO}=3.02, \mathrm{~S}=1.03)^{\prime \prime}$ maddesine gösterilmiştir.

Katılımcılar, kişisel gelişim boyutunda yer alan beş maddenin üçüne "Katıllyorum", ikisine ise “Orta Derecede Katılıyorum" yanıtını vermiştir. Katılımcıların en yüksek katılım gösterdiği madde "Öğretmenlik alanım ile ilgili olmasa da düzenli olarak kitap okurum ( $\mathrm{AO}=3.79$, S.95)" maddesi, en düşük katılım gösterdiği madde ise "Öğretmenlik alanım ile ilgili bilimsel toplantıları (kongre, sempozyum gibi) takip ede$\operatorname{rim}(\mathrm{AO}=3.26, \mathrm{~S}=.99)^{\prime \prime}$ maddesidir.

Katılımciların iş doyumu ( $\mathrm{AO}=3.57, \mathrm{~S}=.63$ ) düzeyi ise "beni oldukça tatmin eder" seçeneğine daha yakındır. Öğretmenler, ölçekte bulunan 14 madde içerisinde, dokuz maddeye "Beni oldukça tatmin eder", beş maddeye ise "Beni orta düzeyde tatmin eder" yanıtını vermiştir. Katılımcıların en yüksek katılım gösterdiği iki madde "İş sırasında birlikte çalıştığım arkadaşlarımı tanıma şansımın olması ( $\mathrm{AO}=3.97$, $\mathrm{S}=.76)$ " ve "İş arkadaşlarım ve etkileşimde bulunduğum kişiler ile iletişimim ( $\mathrm{AO}=3.96$, $\mathrm{S}=.85$ )" maddeleridir. En düşük katılım gösterilen iki madde ise "Aldığım maaş ve ücretin miktarı (AO=3.09, S=1.06)" ve "İşimin sağladığı yükselme ve kişisel gelişme olanağ $(\mathrm{AO}=3.11$, $\mathrm{S}=1.06$ )" maddeleridir.
Katılımciların Duygusal Emek $[\mathrm{t}(361)=1.73$, $\mathrm{p}>$.05], Kişisel Gelişim [t(361) $=0.92, \mathrm{p}>.05]$, Mesleki Duyarlılık [t(361) $=0.48, p>.05]$, Mesleki Profesyonellik Toplam Puan [ $\mathrm{t}(361)=0.63, \mathrm{p}>.05]$ ve İş Doyumu [t(361)=0.92, p>.05] ile görüşleri cinsiyete göre değişmemektedir. Katılımcların Kuruma Katk1 [t(361)=2.86, p<.05] boyutundaki görüşleri ise cinsiyete göre değişmektedir. Erkek öğretmenler (AO=3.71, S=.59) kadın öğretmenlere $(\mathrm{AO}=3.52, \mathrm{~S}=.65)$ göre kurumlar1na daha çok katkı yaptığını düşünmektedir.

Katılımciların Mesleki Duyarlılık [F(4358)=2.32; p $>0.05$ ] ve Mesleki Profesyonellik Toplam Puandaki [F(4-358)=1.96; $\mathrm{p}>$.05] görüşleri görev yapılan okul türüne göre değişmezken; Kuruma Katk1 [F(4-358)=4.35; $\mathrm{p}<.05$ ], Duygusal Emek [F(4-358)=3.06; $\mathrm{p}<.05]$, Kişisel Gelişim $[\mathrm{F}(4-358)=4.71 ; \mathrm{p}<.05]$ ve İş Doyumu [F(4$358)=6.38$; $p<.05$ ] ile ilgili görüşleri görev yapılan okul türüne göre değişmektedir.

Kuruma katkı boyutundaki farklılık en düşük ortalamaya sahip olan okulöncesi öğretmenleri $(\mathrm{AO}=3.32, \mathrm{~S}=.77)$ ile en yüksek iki ortalamaya sahip olan ilkokul ( $\mathrm{AO}=3.77, \mathrm{~S}=.50)$ ve ortaokul $(\mathrm{AO}=3.71, \mathrm{~S}=.61) \quad$ öğretmenleri arasındadır. Duygusal emek boyutundaki farklılık ise en yüksek ortalamaya sahip olan okulöncesi öğretmenleri $(\mathrm{AO}=4.46, \mathrm{~S}=.56)$ ile en düşük ortalamaya sahip olan meslek lisesi öğretmenleri $(\mathrm{AO}=4.15, \mathrm{~S}=.49)$ arasındadır. Kişisel gelişim boyutundaki farklılık da en düşük ortalamaya sahip olan okulöncesi öğretmenleri $(\mathrm{AO}=3.12$, $\mathrm{S}=.68)$ ile en yüksek üç ortalamaya sahip olan genel lise öğretmenleri $(\mathrm{AO}=3.70, \mathrm{~S}=.69)$, ortaokul ( $\mathrm{AO}=3.57, \mathrm{~S}=.62)$ ve meslek lisesi öğretmenleri $(\mathrm{AO}=3.55, \mathrm{~S}=.69)$ arasindadir.

İş doyumundaki farklılık ise, en yüksek ortalamaya sahip olan okulöncesi öğretmenleri ( $\mathrm{AO}=4.00, \mathrm{~S}=.53)$, en düşük üç ortalamaya sahip olan meslek lisesi ( $\mathrm{AO}=3.41, \mathrm{~S}=.68)$, ilkokul $(\mathrm{AO}=3.52, \mathrm{~S}=.50)$ ve ortaokul $(\mathrm{AO}=3.59, \mathrm{~S}=.63)$ öğretmenleri arasındadır. Okulöncesi öğret- 
menleri ile meslek lisesi, ilkokul ve ortaokul öğretmenleri arasındaki farklılık istatiksel olarak anlamlıdir.

Katılımcıların kıdemleri "1-5 yıl, 6-10 yıl, 11-15 yıl, 16-20 yıl, 21 yıl ve üstü” olmak üzere beş grupta incelenmiştir. Katılımcıların, Kuruma katk1 $[\mathrm{F}(4-356)=1.82 ; \mathrm{p}>0.05]$, Duygusal emek $[F(4-356)=0.70 ; \quad p>0.05]$, Kişisel gelişim $[F(4-$ 356)=1.43; p>0.05], Mesleki Duyarlılık [F(4356) $=0.40 ; p>0.05]$, Mesleki Profesyonellik Toplam Puan $[\mathrm{F}(4-356)=0.86 ; \mathrm{p}>0.05]$ ve İş Doyumu $[F(4-356)=0.75 ; p>0.05]$ ile ilgili görüşleri kıdeme göre değişmemektedir.

Katılımcıların görev yaptıkları okullardaki öğretmen sayısı “1-25, 26-50, 51 ve üstü” olmak üzere üç grupta incelenmiştir. Katılımcıların, Kuruma katk1 [F(2-355)=0.72; p >0.05], Duygusal emek $[\mathrm{F}(2-355)=0.29 ; \mathrm{p}>0.05]$, Kişisel gelişim [F(2-355)=1.58; p>0.05], Mesleki Duyarlılık [F(2355)=2.07; $\mathrm{p}>0.05$ ] ve Mesleki Profesyonellik Toplam Puandaki [F(2-355)=0.39; p>0.05] görüşleri okuldaki öğretmen sayısına göre değişmemektedir. Katılımcıların İş doyumu ile ilgili görüşleri ise okuldaki öğretmen sayısına göre değişmektedir $[\mathrm{F}(2-355)=8.29 ; \mathrm{p}<0.05]$. Buradaki farklılık, en yüksek ortalamaya sahip olan okuldaki öğretmen sayısı 1-25 olan okullarda göre yapan öğretmenler $(\mathrm{AO}=3.68, \mathrm{~S}=.60)$ ile en düşük ortalamaya sahip olan okuldaki öğretmen sayısı 51 ve üstünde $(\mathrm{AO}=3.33, \mathrm{~S}=.69)$ olan okullarda göre yapan öğretmenler arasındadır. Aritmetik ortalamalara göre öğretmenlerin iş doyumu düzeyi mesleki kıdem arttıkça düşmektedir.

Katılımciların, kuruma katkı $(\mathrm{r}=.27, \mathrm{p}<.01)$, kişisel gelişim $(\mathrm{r}=.22$, $\mathrm{p}<.01)$ ve mesleki duyarl1lik $(\mathrm{r}=.20, \mathrm{p}<.01)$ ile ilgili görüşleri ile iş doyumu arasında düşük düzeyde, aynı yönde ve anlamli; duygusal emek ( $\mathrm{r}=.37, \mathrm{p}<.01)$ ve mesleki profesyonellik toplam puan $(\mathrm{r}=.35, \mathrm{p}<.01)$ ile ilgili görüşleri arasında ise orta düzeyde, aynı yönde ve anlamlı ilişkiler vardır.

\section{SONUÇ VE TARTIŞMA}

$\mathrm{Bu}$ araştırmada öğretmenlerin mesleki profesyonellikleri ile iş doyumları arasındaki ilişki belirlenmeye çalışılmıştır. Öğretmenler kendilerini mesleki duyarlılık boyutunda, diğer boyutlara göre daha profesyonel görmektedir. $\mathrm{Bu}$ boyutu sirası ile duygusal emek, kuruma katkı ve kişisel gelişim boyutları izlemektedir. Mesleki duyarlılık, gereksinimlerinin farkında olmak, yeni fikirlere ve değişime açık olmak, meslektaşlarıyla iletişim ve işbirliği içinde çalışmak, mesleki etik ilkelere duyarlı olmak, işini en iyi biçimde yapma gayretinde olmak ve davranışlarıyla öğrencilere rol model olmak gibi davranışlarla ilgilidir. Katılımcılar, meslektaşlarımla bilgi alış verişinde bulunmanın önemli olduğunu düşünmektedir. Ayrıca göreceli olarak daha düşük katılım gösterilse de katılımcılar, öğretmenlikleri ile ilgili konularda geri bildirim almaktan da mutlu olacaklarını belirtmiştir. Bu sonuçlar birbirinden öğrenen bir okul oluşturulması açısından çok önemlidir. Bilginin paylaşıldığı, geri bildirimler ile etkinliklerin zenginleştirildiği bir okul ortamı öğrencilerin öğrenmeleri açısından da önemlidir.

İkinci sırada yer alan duygusal emek boyutu, öğretmenlerin mevcut duygu durumu ne olursa olsun bunu eğitim öğretim sürecine yansıtmaması olarak görülebilir. Çünkü duygusal emek, çalışanların mesleki profesyonelliklerinin bir gereği olarak, örgütsel amaçlara ve çalışma ortamına uygun davranışlar sergileyebilmeleri için gerçek duygularını düzenlemesi (Isenbarger ve Zembylas, 2006) ve duygularını yönetmesidir. Katılımcılar bu boyutta en çok öğretmenlik mesleği etik ilkelerine uygun davrandıklarını belirtmiştir. Öğretmenler, görece daha düşük düzeyde ise çocuklarının gelişimi konusunda öğrenci velilerine düzenli geri bildirimde bulunduklarını ifade etmiştir.

Mesleki duyarlılık ve duygusal emek boyutları, mesleki profesyonelliğin daha çok mesleğin 
devam ettirilmesi ile ilgili boyutlarını içermektedir. Kuruma katkı ve kişisel gelişim boyutları ise daha çok, kişinin mesleğini daha iyi yapabilmesi için kendisini ve kurumunu geliştirme çabası içinde olması ile ilgilidir. Mesleki profesyonellik açısından düşünüldüğünde kuruma katkı ve kişisel gelişim diğer boyutlara göre çok daha önemlidir. Çünkü bir işi profesyonelce yapmak, kişinin kendi mesleki gelişim ve ilerlemesi için sorumlu olmasıdır (Doreen ve Prieur, 1996). Toh, Diong, Boo ve Chia (1996) yaptıkları araştırmada öğretmen profesyonelliğinin en önemli belirleyicisinin mesleki gelişim olduğunu belirlemiş̧ir.

Katılımclar kuruma katkı ile ilgili olarak, en çok bilgi ve iletişim teknolojilerini dersi geliştirmek için kullandıklarını, en az ise okuldaki sorunlar ile ilgili bilimsel araştırmalar yaptıklarını belirtmiştir. Bilimsel araştırma bulgusuna paralel olarak, kişisel gelişim boyutunda en az yapılan davranış da, öğretmenlik alanı ile ilgili bilimsel toplantıları (kongre, sempozyum gibi) takip etme davranışıdır. Bu bulgular öğretmenlerin bilimsel araştırma yapma ve bilimsel araştırmaları takip etme konusunda çok da profesyonelce davranmadıklarını gösterdiği söylenebilir. Katılımcıların, öğretmenlik alanı ile ilgili olmasa da düzenli olarak kitap okuma davranışı da çok yüksek düzeyde çıkmamaktadır. Türkiye'de genel okuma kültürünün (Kültür Bakanlığı, 2013) ve öğretmenlerin okuma alışkanlığı (Özen, 1998; Yılmaz, 2006) düzeyinin düşük olduğu düşünüldüğünde, bu bulguya çok da şaşırılmamalıdır. Ancak okumayı ve öğrenmeyi bırakan öğretmen, gelişmeyi de bırakmış demektir.

Öğretmenlerin kuruma katkı ve kişisel gelişim ile ilgili görüşleri katılıyorum yanıtına daha yakın olsa da, bu boyutlarda daha yüksek bir katılım düzeyi beklenebilir. Katılımclar, mesleki duyarlılık ve duygusal emek boyutlarma, kuruma katkı ve kişisel gelişim boyutlarına göre daha yüksek katılım göstermiştir. Türk eğitim sistemi gibi sürekli olarak değişim yaşanan bir eğitim sisteminde, öğretmenlerin sürekli bir gelişim çabası içinde olması önemlidir. Katılımclların, mesleki profesyonellik toplam puandaki görüşlerinin de katılıyorum yanıtına daha yakın olması bu bağlamda önemlidir. Buna göre öğretmenler kendilerini oldukça yüksek düzeyde profesyonel olarak görmektedir. Bayhan (2011) doktora tez çalışmasında, öğretmenlerin profesyonellik algısını, "Mesleki Yeterlik, Profesyonel Yaklaşım ve Etkililik" alt boyutlarında ve Profesyonellik Toplam Puanda incelemiştir. Bayhan (2011) öğretmenlerin mesleki ve bireysel profesyonellik algılarının yüksek olduğu, ancak bu düzeyin daha çok sınıf ve öğrenci alanlarında sınırlı kaldığını saptamıştır. Cerit ise (2012) araştırmasında öğretmenlerin profesyonel davranışları sergileme düzeyinin ortalama değerin altında olduğunu belirlemiştir.

Katılımcıların iş doyumu düzeyi "beni oldukça tatmin eder" yanıtına daha yakındır. Daha önce yapılan araştırmalarda da (Günbayı, 2000; Koç, Yazıcıoğlu ve Hatipoğlu, 2009; Yılmaz, 2012) öğretmenlerin iş doyumu düzeylerinin orta düzeyde olduğu belirlenmiştir. İş doyumunun yüksek olması mesleki profesyonellik açısından çok önemlidir. Çünkü iş doyumu ve yeterlik, öğretmenlerin profesyonelliklerini sürdürmelerinde önemli değişkenlerdir (Pillay, Goddard \& Wilss, 2005). Yüksek düzeyde doyuma sahip öğretmenlerin işe ilişkin tutumlarının olumlu olacağı, daha istekli, verimli ve etkili olacağ 1 söylenebilir. Tersi durumda da yani işinden memnun olmayan, örgüte yaptığı katkı oranında kazanım elde edemediğini düşünen bir çalışanın da örgüt yararına bir şeyler yapma istekliliğinde olmasını beklemek de zordur (Altınkurt \& Yılmaz, 2012). Katılımciların en yüksek iş doyumu sağladığı konu, çalışma arkadaşlarıdır. Katılımcılar, iş sırasında birlikte çalıştığı arkadaşlarını tanıma şansının olması- 
nın ve bu kişiler ile iletişim içinde olmalarının iş doyumlarını artırdığını belirtmiştir. Katılımcllara daha düşük düzeyde iş doyumu sağlayan konular ise, "alınan maaş-ücret" ve "işteki yükselme ve kişisel gelişme" olanağıdır.

Katılımcıların, duygusal emek, kişisel gelişim, mesleki duyarlılık, mesleki profesyonellik toplam puan ve iş doyumu ile görüşleri cinsiyete göre değişmemektedir. Bayhan da (2011) araştırmasında katılımcıların profesyonellik toplam puan, profesyonel yaklaşım ve etkililik alt boyutlarındaki görüşlerinin cinsiyete göre değişmediğini belirlemiştir. Aynı araştırmada, kadın öğretmenlerin erkek öğretmenlere göre, kendilerini mesleki yeterlik açısından daha yeterli algıladıkları belirlenmiştir.

Katılımcıların kuruma katkı boyutundaki görüşleri ise cinsiyete göre değişmektedir. Erkek öğretmenler kadın öğretmenlere göre kurumlarına daha çok katkı yaptığını düşünmektedir. Kuruma katkı boyutu, öğretmenlerin sahip olduğu bilgi, birikim, deneyim ve çevresindeki ilişkilerini kurum yararına kullanması ile ilgilidir. Birçok eğitim sisteminde olduğu gibi Türk eğitim sisteminde görev yapan okul müdürleri arasında kadın okul müdürlerinin sayısı çok azdır. Bu durum erkek okul müdürlerinin daha çok erkek müdür yardımcıları ile çalışmasına yol açmaktadır. Erkek öğretmenlerin kurumlarına daha çok katkı yaptıklarını düşünmelerinin sebebi bu olabilir. Ayrıca Türkiye'nin ataerkil toplum yapısı ve kadına iş dışında yüklenen görevlerin çokluğu da bu bulgunun nedeni olabilir.

Katılımcıların, mesleki duyarlılık ve mesleki profesyonellik toplam puandaki görüşleri görev yapılan okul türüne göre değişmezken; kuruma katkı, duygusal emek, kişisel gelişim ve iş doyumu ile ilgili görüşleri görev yapılan okul türüne göre değişmektedir. Kuruma katkı boyutunda en düşük ortalamaya okulöncesi öğretmenleri sahipken, en yüksek iki ortalama- ya ilkokul ve ortaokul öğretmenleri sahiptir. Kişisel gelişim boyutunda da en düşük ortalamaya okulöncesi öğretmenleri, en yüksek üç ortalamaya ise genel lise öğretmenleri, ortaokul ve meslek lisesi öğretmenleri sahiptir. Duygusal emek boyutunda da en yüksek ortalamaya okulöncesi öğretmenleri sahipken, en düşük ortalamaya meslek lisesi öğretmenleri sahiptir.

Görüldüğü gibi okulöncesi öğretmenleri kuruma katkı ve kişisel gelişim gibi alanlarda kendilerini daha az profesyonel algılarken, duygusal emek boyutunda daha fazla profesyonel algılamaktadır. Okulöncesi öğretmenliğinin diğer öğretmenlik alanlarına göre daha duygu yoğun olması, öğrencilerin çok küçük yaşlarda ve korunmaya daha muhtaç bir dönemde olması, okulöncesi öğretmenlerinin duygusal emek algısının daha yüksek çıkmasına sebep olabilir. Ayrıca okulöncesi eğitim kurumlarının diğer eğitim kurumlarına göre daha küçük olması, bu okullarda çalışan öğretmenlerin kuruma katkı ve kişisel gelişim boyutlarında kendilerini daha az profesyonel algılamalarına sebep olabilir. İş doyumu konusunda elde edilen bulgular da bu bulguyu destekler niteliktedir. İş doyumunda en yüksek ortalamaya okulöncesi öğretmenleri, en düşük üç ortalamaya ise meslek lisesi, ilkokul ve ortaokul öğretmenleri sahiptir. Okulöncesi öğretmenleri ile meslek lisesi, ilkokul ve ortaokul öğretmenleri arasındaki farklılık istatiksel olarak anlamlıdır.

Katılımciların, kuruma katkı, duygusal emek, kişisel gelişim, mesleki duyarlılık, mesleki profesyonellik toplam puan ve iş doyumu ile ilgili görüşleri kıdeme göre değişmemektedir. Buna göre mesleki profesyonellik algısının kıdem değişkeninden etkilenmediği söylenebilir. Mesleki profesyonellik bireysel bir özelliktir, çünkü öğretmenlerin profesyonellik algısı onların içselleştirmiş inanç ve değerlerince belirlenmektedir (Phelps, 2006). Bundan dolayı, 
öğretmenin kıdemi ne olursa olsun, her dönemde işini profesyonelce yapması, onun mesleki inanç ve değerleri ile ilgili bir durumdur. Toh ve diğerleri (1996) ve Bayhan da (2011) öğretmenlerin profesyonellik algısının kıdeme göre değişmediğini belirlemiştir.

İş doyumu ile ilgili olarak, kıdeme göre fark belirleyen araştırmalar (Çetinkanat, 2000) olduğu gibi belirlemeyen araştırmalar da (Balc1, 1985; Günbayı, 2000; Yılmaz, 2012) vardır. Son yıllarda yaş ve kıdem ile iş doyumu arasındaki ilişki " $U$ " harfine benzetilmektedir. Mesleğin başlarında yüksek, ortalarında düşük, mesleğin sonlarına doğru ise yine düşük olduğu ileri sürülmektedir.

Katılımcıların, kuruma katkı, duygusal emek, kişisel gelişim, mesleki duyarlılık ve mesleki profesyonellik toplam puandaki görüşleri okuldaki öğretmen sayısına göre değişmemektedir. Buna göre okulun büyüklüğünün öğretmenlerin mesleki profesyonellik algısını etkilemediği söylenebilir.

Katılımcıların iş doyumu ile ilgili görüşleri ise okuldaki öğretmen sayısına göre değişmektedir. Buradaki farklılık, en yüksek ortalamaya sahip olan, “okuldaki öğretmen sayısı 1-25" olan okullarda göre yapan öğretmenler ile en düşük ortalamaya sahip olan "okuldaki öğretmen sayısı 51 ve üstünde" olan okullarda göre yapan öğretmenler arasındadır. Aritmetik ortalamalara göre öğretmenlerin iş doyumu düzeyi mesleki kıdem arttıkça düşmektedir. Öğretmen sayısının fazla olması örgütün büyüklüğüne işaret etmektedir. Örgütler büyüdükçe, çalışanlar arasındaki ilişkiler zayıflamakta, yönetimin çalışanlar üzerindeki kontrolü azalmakta, çalışan devamsızlığı artabilmekte, verimlilik düşebilmektedir. Yılmaz da (2012) öğretmenlerin iş doyumunun okuldaki öğretmen sayısına göre değiştiğini ve daha büyük okulda çalışan öğretmenlerin iş doyumunun daha düşük olduğunu belirlemiştir. Öğretmen sayısının fazla olması o okulda öğrenci sayısının ve dolayısıyla yapılan iş ve işlemlerin de daha fazla olması anlamına gelmektedir. Büyük okullarda bu anlamda öğretmen, öğrenci ve yöneticilerin kendi aralarında ve birbirleriyle olan ilişki ve iletişimleri daha formal olabilmektedir.

Katılımcıların, kuruma katkı, kişisel gelişim ve mesleki duyarlılık ile ilgili görüşleri ile iş doyumu arasında düşük düzeyde, aynı yönde ve anlamlı; duygusal emek ve mesleki profesyonellik toplam puan ile ilgili görüşleri arasında ise orta düzeyde, aynı yönde ve anlamlı ilişkiler vardır. Buna göre katılımcıların mesleki profesyonellik ve alt boyutları ile ilgili olumlu görüşleri arttıkça iş doyum düzeyleri de yükselmektedir. Öğretmenlerin özellikle duygusal emek ve mesleki profesyonellik toplam puan ile ilgili görüşlerinin olumlu olması iş doyumunu artırıcı bir etkiye sahiptir. Kişinin yaptığı işi profesyonelce yapmasının, yaptığı işten sağladığı doyumu da artırdığı söylenebilir.

Bayhan (2011) araştırmasında öğretmenlerin profesyonelliğinde etkili aktörler konusunda öğretmenlerin görüşlerini belirlemiştir. Buna göre öğretmenler, öğretmenlerin mesleki profesyonelliklerinde “öğretmenlerin kendisinin, okul yönetiminin, bakanlığın ve eğitim fakültelerinin" etkili olduğunu düşünmektedir. Bu bağlamda öğretmenlerin kendilerinin, okul yöneticilerinin, Bakanlığın ve eğitim fakültelerinin bu konudaki farkındalıkları artırılmalıdır. $\mathrm{Bu}$ araştırmada öğretmenlerin özellikle kişisel gelişim ve kuruma katkı puanları, diğer boyutlara göre düşük çıkmıştır. Öğretmenlerin mesleki profesyonellik ve mesleki gelişim konusundaki farkındalıkları da artırılmalıdır.

Hargreaves (2000) öğretmen profesyonelliğini, uygulamaların standart ve niteliğinin geliştirilmesi olarak tanımlamıştır. $\mathrm{Bu}$ bağlamda öğretmen profesyonelliğinde eğitim-öğretimin niteliğinin geliştirilmesi önemli bir yere sahip- 
tir. Öğretmenlere bu yönde fırsatlar, bilgilerini paylaşacak ortamlar sağlanmalıdır. Öğretmenlere, bilimsel toplantılara katılmaları yönünde 2012 yılında verilmeye başlanan destekler geliştirilerek devam etmelidir. Bu bağlamda, öğretmenlerin okuldaki sorunlar ile ilgili bilimsel araştırmalar yapması özendirilmelidir.
Bundan sonra yapılacak araştırmalarda, mesleki profesyonellik algısı ile bireysel ve örgütsel düzeydeki birçok değişkenin ilişkisi araştırma konusu yapılabilir. Ayrıca mesleki profesyonellik algısı ile ilgili nitel araştırmalar tasarlanabilir.

\section{Kaynakça}

Adıgüzel, O., Tanrıverdi, H. ve Sönmez-Özkan, D. (2011). Mesleki Profesyonellik ve Bir Meslek Mensupları Olarak Hemşireler Örneği. Yönetim Bilimleri Dergisi, 9 (2), 237-259.

Altınkurt, Y. ve Yılmaz, K. (2012). Ortaöğretim Okullarında Değerlerle Yönetim, Örgütsel Adalet ve İş Doyumu Arasındaki İlişki. Sakarya Üniversitesi Eğitim Fakültesi Dergisi, 2 (4), 50-68.

Balcı, A. (1985). Ĕğitim Yöneticisinin İş Doyumu. Yayımlanmamış doktora tezi. Ankara Üniversitesi, Ankara.

Basım, N. ve Begenirbaş, M. (2012). Çalışma Yaşamında Duygusal Emek: Bir Ölçek Uyarlama Çalışması. Yönetim ve Ekonomi, 19 (1), 77-90.

Bayhan, G. (2011). Öğretmenlerin Profesyonelliğinin İncelenmesi. Yayımlanmamış doktora tezi. Marmara Üniversitesi Eğitim Bilimleri Enstitüsü, İstanbul.

Boyt, T., Lusch, R. F. and Naylor, G. (2001). The Role of Professionalism in Determining Job Satisfaction in Professional Services: A Study of Marketing Researchers. Journal of Service Research, 3 (4), 321330.

Büyüköztürk, Ş. (2009). Sosyal Bilimler İçin Veri Analizi El Kitabı. Ankara: Pegem Akademi.

Cerit, Y. (2012). Okulun Bürokratik Yapısı İle Sınıf Öğretmenlerinin Profesyonel Davranışları Arasındaki İlişki. Kuram ve Uygulamada Eğitim Yönetimi, 18 (4), 497-521.

Çetinkanat, C. (2000). Örgütlerde Güdülenme ve İş Doyumu. Ankara: Anı Yayıncılık.

Demirkasımoğlu, N. (2010). Defining “Teacher Professionalism" from Different Perspectives. Procedia Social and Behavioral Sciences, 9, 2047-2051.

Diefendorff, J. M., Croyle, M. and Gosserand, R. H. (2005). The Dimensionality and Antecedents of Emotional Labor Strategies. Journal of Vocational Behavior, 66, 339-357.

Doreen, S. and Prieur, P. D. (1996). Teacher Professionalism and School Leadership: An Antithesis? Education, 116 (3), 393-396.

Evans, L. (1999). Managing to Motivate: A Guide for School Leaders. London: Cassell.

Freidson, E. (2001). Professionalism: The Third Logic. Oxford: Polity Press.

Günbayı, İ. (2000). Örgütlerde İş Doyumu ve Güdülenme. Ankara: Özen Yayımcılık.

Hackman, J. R. and Oldman, G. R. (1975). Development of the Job Diagnostic Survey. Journal of Applied Psychology, 60 (2), 159-170. 
Hargreaves, A. (2000). Four ages of Professionalism and Professional Learning. Teachers and Teaching: Theory and Practice, 6 (2), 151-182.

Isenbarger, L. and Zembylas, S. M. (2006). The Emotional Labor of Caring in Teaching. Teaching and Teacher Education, 22, 120-134.

Koç, H., Yazıcıŏ̆lu, İ. ve Hatipoğlu, H. (2009). Öğretmenlerin İş Doyum Algıları İle Performansları Arasındaki İlişkinin Belirlenmesine Yönelik Bir Araştırma. Ondokuz Mayıs Üniversitesi Ĕ̆itim Fakültesi Dergisi, 28, 13-22.

Kültür Bakanlığı (2013). Türkiye'de Okuma Kültürü Haritası Projesi. Ankara: T.C. Kültür ve Turizm Bakanlığı. http://www.kygm.gov.tr/Eklenti/55,yonetici-ozetipdf.pdf?0 adresinden erişildi.

Locke, E. (1983). Nature and Causes of Job Satisfaction. Handbook of Industrial and Organizational Psychology (Ed: J. Durnette). USA: Wiley and Sons. pp. 1297-1349.

Luthans, F. (1992). Organizational Behavior. NY: Mc Graw Hill.

McMahon, E. and Hoy, W. K. (2009). Professionalism in Teaching: Toward a Structural Theory of Professionalism. In Wayne K. Hoy \& Michael DiPaola (Eds.). Studies in school improvement. Greenwich, CN: Information Age. pp. 205-230.

Muchinsky, P. M. (2006). Psychology Applied to Work. CA: Thomson Higher Education.

Murphy, G. A. and Calway, B. A. (2008). Professional Development for Professionals: Beyond Sufficiency Learning. Australian Journal of Adult Learning, 48 (3), 424-444.

Özen, F. (2-6 Şubat 1998). Türkiye'de Okuma Alışkanlığı ve Öğretmenin Sorumluluğu. Ĕğitim Sen Demokratik Ĕgitim Kurultayı. Ankara: Volkan Matbaası. ss. 571-590.

Pearson, L. C. and Moomaw, W. (2005). The Relationship between Teacher Autonomy and Stress, Work Satisfaction, Empowerment, and Professionalism. Educational Research Quarterly, 29, 38-54.

Phelps, H. P. (2006). The Three Rs of Professionalism. Kappa Delta Pi Record, 42 (2), 69-71.

Pillay, H., Goddard, R. and Wilss, L. (2005). Well-being, Burnout and Competence: Implications for Teachers. Australian Journal of Teacher Education, 30 (2), 22-33.

Spector, P. E. (1997). Job Satisfaction: Application, Assessment, Cause, and Consequences. California: SAGE.

Swisher, L. L. and Page, C. G. (2005). Professionalism in Physical Therapy. St. Louis: St. Louis: Elsevier.

Taşdan, M. (2008). Kamu ve Özel İlköğretim Okullarında Görevli Öğretmenlerin Değer, İş Doyumu ve Öğretmene Mesleki Sosyal Destek İle İlgili Görüşleri. Yayınlanmamış doktora tezi. Ankara Üniversitesi Eğitim Bilimleri Enstitüsü.

Toh, K., Diong, C., Boo, H. and Chia, S. (1996). Determinants of Teacher Professionalism. British Journal of In-Service Education, 22 (2), 231-244,

Türk Dil Kurumu (2005). Türkçe Sözlük. Ankara: Türk Dil Kurumu Yayınları.

Yılmaz, B., Korkut, Ş. ve Köse, E. (2010). Ankara'daki Üniversite ve Halk Kütüphanelerinde Çalışan Kütüphanecilerin İş Doyumları Üzerine Bir Araştırma. Bilgi Dünyası, 11 (1), 49-80. 
Yılmaz, K. (2012). İlköğretim Okulu Öğretmenlerinin İş Doyumu Düzeyleri İle Örgütsel Vatandaşlık Davranışları Arasındaki İlişki. Anadolu Journal of Educational Sciences International, 2 (2), 1-14.

Yılmaz, K. ve Altınkurt, Y. (2014). Öğretmenlerin mesleki profesyonelliği ölçeği geçerlik ve güvenirlik çalışması. Uluslararası İnsan Bilimleri Dergisi, 11 (2), BASKIDA. http://www.insanbilimleri.com.

Yılmaz, Z. A. (2006). Sınıf Öğretmeni Adaylarının Okuma Alışkanlığı. İköğgretim Online, 5 (1), 1-6. http://ilkogretim-online.org.tr adresinden erişildi. 


\section{Extended Summary}

Professionalism focuses on what are the qualifications and capacities gained as well as the competencies required for successful performance of a task (Demirkasımoğlu, 2010). Occupational professionalism is also considered one of the fundamental factors in the determination of occupational standards, as well as improvement of the quality of service (Adıgüzel, Tanrıverdi and Sönmez-Özkan, 2011). This study examines occupational professionalism of teachers under the following sub-dimensions: 1) Personal development, 2) Contribution to organization, 3) Professional awareness, and 4) Emotional labor. Job satisfaction, in its simplest terms, is defined as employees' feeling of love and satisfaction regarding their jobs (Locke, 1983; Spector, 1997; Muchinsky, 2006) or as a level at which employees are happy and satisfied about their jobs (Hackman \& Oldham, 1975). The purpose of this research study is to determine the relationship between the occupational professionalism of teachers and their job satisfaction. In order to reach this overall aim, responses to the following questions are sought: 1) What are participants' opinions about occupational professionalism and job satisfaction? 2) Do participants' opinions about occupational professionalism and job satisfaction vary according to gender, school type, seniority and the number of teachers working in the school? 3) Is there a significant relationship between participants' opinions about occupational professionalism and job satisfaction?

Designed in survey method, the sample of this research is comprised of 363 teachers working in schools in Kütahya city center. Data was collected using the Occupational Professionalism of Teachers Scale and Job Satisfaction Scale. The Occupational Professionalism of Teachers Scale is comprised of four factors, namely Personal Development, Contribution to Organization, Professional Awareness and Emotional Labor. Data analysis has included descriptive statistics, t-test, ANOVA and Pearson correlation coefficient.

Teachers in the study ( $\mathrm{n}=363)$, among various dimensions of occupational professionalism, favored mostly Professional Awareness ( $\mathrm{M}=4.41, \mathrm{~S}=.56$-Strongly agree), followed by Emotional Labor $(\mathrm{M}=4.24$, $\mathrm{S}=.53$-Strongly agree), Contribution to Organization ( $\mathrm{M}=3.62, \mathrm{~S}=.62$-Agree), and Personal Development $(\mathrm{M}=3.51, \mathrm{~S}=.62$-Agree). Total score of the participants on Occupational Professionalism ( $\mathrm{M}=3.92, \mathrm{~S}=.45)$ was closer to Agree.

Job satisfaction of the participants $(\mathrm{M}=3.57, \mathrm{~S}=.63)$ was closer to "Very satisfied". Teachers responded "Very satisfied" to nine items out of 14 in the scale, while "Somewhat Satisfied" to five items. The two items with the highest score were "Having an opportunity to know my colleagues" (M=3.97, S=.76) and "Communication with my colleagues and people I interact with" (M=3.96, S=.85). The items with the lowest score were "Amount of my salary and other wages" (M=3.09, $\mathrm{S}=1.06)$ and "Opportunities for promotion and personal development provided by my job" (M=3.11, $\mathrm{S}=1.06)$.

Participants' opinions about Emotional Labor [t(361)=1.73, p>.05], Personal Development $[\mathrm{t}(361)=0.92$, $\mathrm{p}>$.05], Professional Awareness [t(361) $=0.48, \mathrm{p}>.05]$, Occupational Professionalism Total Score $[\mathrm{t}(361)=0.63, \mathrm{p}>.05]$ and Job Satisfaction $[\mathrm{t}(361)=0.92, \mathrm{p}>.05]$ did not vary as of gender. Participants' opinions about Contribution to Organization $[\mathrm{t}(361)=2.86, \mathrm{p}<.05]$, on the other hand, changed based on gender. Compared to female teachers $(\mathrm{M}=3.52, \mathrm{~S}=.65)$, male teachers $(\mathrm{M}=3.71, \mathrm{~S}=.59)$ thought that they contributed to their organizations a great deal. 
Participants' opinions on Professional Awareness [F(4-358)=2.32; $\mathrm{p}>0.05]$ and their Occupational Professionalism Total Score $[\mathrm{F}(4-358)=1.96 ; \mathrm{p}>.05]$ did not vary as of the school type, whereas their opinions about Contribution to Organization $[\mathrm{F}(4-358)=4.35$; $\mathrm{p}<.05]$, Emotional Labor [F(4-358)=3.06; $\mathrm{p}<.05]$, Personal Development $[\mathrm{F}(4-358)=4.71 ; \mathrm{p}<.05]$ and Job Satisfaction $[\mathrm{F}(4-358)=6.38 ; \mathrm{p}<.05]$ changed based on school type.

The difference with regard to the contribution to organization was between the pre-school teachers with the lowest average $(\mathrm{M}=3.32, \mathrm{~S}=.77)$ and elementary school $(\mathrm{M}=3.77, \mathrm{~S}=.50)$ and middle school teachers $(\mathrm{M}=3.71, \mathrm{~S}=.61)$ with the highest average. Difference with regard to the emotional labor was between the pre-school teachers with the highest average $(\mathrm{M}=4.46, \mathrm{~S}=.56)$ and vocational school teachers $(\mathrm{M}=4.15$, $\mathrm{S}=.49$ ) with the lowest average. Difference with regard to the personal development was between the pre-school teachers with the lowest average $(\mathrm{M}=3.12, \mathrm{~S}=.68)$ and the high school teachers $(\mathrm{M}=3.70, \mathrm{~S}=.69)$, middle school teachers $(\mathrm{M}=3.57, \mathrm{~S}=.62)$ and vocational high school teachers $(\mathrm{M}=3.55, \mathrm{~S}=.69)$ with the highest average.

Difference with regard to the job satisfaction was between the pre-school teachers with the highest average $(\mathrm{M}=4.00, \mathrm{~S}=.53)$ and vocational high school teachers $(\mathrm{M}=3.41, \mathrm{~S}=.68)$, elementary school teachers $(\mathrm{M}=3.52, \mathrm{~S}=.50)$ and middle school teachers $(\mathrm{M}=3.59, \mathrm{~S}=.63)$ with the lowest average. The difference between the pre-school teachers and vocational high school teachers, elementary school teachers and middle school teachers is statistically significant.

Seniority of the participants were examined under five groups: 1-5 years, 6-10 years, 11-15 years, 16-20 years, and 21 years and above. Participants' opinions about Contribution to Organization $[\mathrm{F}(4-356)=1.82$; $\mathrm{p}>0.05]$, Emotional Labor [F(4-356) $=0.70 ; \mathrm{p}>0.05]$, Personal Development $[\mathrm{F}(4-356)=1.43 ; \mathrm{p}>0.05]$, Professional Awareness $[\mathrm{F}(4-356)=0.40 ; \mathrm{p}>0.05]$, Occupational Professionalism Total Score $[\mathrm{F}(4-356)=0.86$; $\mathrm{p}>0.05]$ and Job Satisfaction $[\mathrm{F}(4-356)=0.75 ; \mathrm{p}>0.05]$ did not vary based on their seniority.

The number of teachers working in participants' schools was examined under three groups: 1-25, 26-50, and 51 and above. Participants' opinions about Contribution to Organization [F(2-355)=0.72; $\mathrm{p}>0.05]$, Emotional Labor $[\mathrm{F}(2-355)=0.29 ; \mathrm{p}>0.05]$, Personal Development $[\mathrm{F}(2-355)=1.58 ; \mathrm{p}>0.05]$, Professional Awareness $[F(2-355)=2.07 ; p>0.05]$ and Occupational Professionalism Total Score $[F(2-355)=0.39 ; p>0.05]$ did not vary based on the number of teachers in their schools. Participants' opinions about job satisfaction, on the other hand, changed as of the number of teachers in their schools $[F(2-355)=8.29 ; p<0.05]$. The difference here was between the teachers working in schools with 1-25 teachers with the highest average $(\mathrm{M}=3.68, \mathrm{~S}=.60)$, and the teachers working in schools with 51 or more teachers with the lowest average $(\mathrm{M}=3.33, \mathrm{~S}=.69)$.

There is a low, even and significant relationship between job satisfaction and participants' opinions about the contribution to organization $(\mathrm{r}=.27, \mathrm{p}<.01)$, personal development $(\mathrm{r}=.22, \mathrm{p}<.01)$ and professional awareness $(\mathrm{r}=.20, \mathrm{p}<.01)$; whereas there is a moderate, even and significant relationship between participants' opinions about emotional labor $(\mathrm{r}=.37, \mathrm{p}<.01)$ and occupational professionalism total score $(\mathrm{r}=.35, \mathrm{p}<.01)$. Accordingly, participants' job satisfaction levels rise as their opinions about occupational professionalism and its sub-dimensions become more positive. In particular, having positive opinions about emotional labor and occupational professionalism total score improves their job satisfaction. Doing one's job in a professional manner improves job satisfaction. 